\title{
Early Childhood Education and Care in England under Austerity: Continuity or Change in Political Ideas, Policy Goals, Availability, Affordability and Quality in a Childcare Market?
}

\author{
JANE LEWIS* AND ANNE WEST** \\ * Department of Social Policy, London School of Economics, Houghton St., London, WC2A \\ 2AE, United Kingdom \\ email: J.Lewis@/se.ac.uk \\ ** Department of Social Policy, London School of Economics, Houghton St., London, WC2A \\ $2 A E$, United Kingdom \\ email: A.West@/se.ac.uk
}

\begin{abstract}
Provision of early childhood education and care (ECEC) in England is highly marketised. Since 2010, when the Labour Party lost power to a Conservative/Liberal Democrat Coalition, followed by a Conservative victory in 2015, there has been a strong austerity agenda. It is therefore surprising that ECEC has continued to be supported and expanded. However, we show that policies to address the three key issues of availability, affordability and quality have undergone significant incremental change in response to shifting emphases between the two main goals of increasing children's development and mothers' employment, together with a much firmer orientation towards the importance of growing the childcare market.
\end{abstract}

\section{Introduction}

Prior to the UK General Election in May 2015, which ushered in a Conservative Government after thirteen years under Labour and five under a Conservative/Liberal Democrat Coalition, it seemed that a political consensus had been established about 'childcare' (Cory, 2015). Labour promised an increase in the 15 free hours entitlement in England ${ }^{2}$ to 25 for three- and four-year olds; the Liberal Democrats promised 20 free hours for two-, three- and four-yearolds; and, surprisingly, the Conservatives promised 30 free hours for three- and four-year-olds. These manifesto promises were made despite, first, the shared concern about deficit-reduction and in particular the Conservative commitment to strong anti-austerity policies; and, second, doubt cast over the outcomes of early childhood education and care (ECEC) policy in terms of both main goals: 
child development and promoting mothers' employment (Blanden et al., 2016; Brewer et al., 2014).

The institutional structure of the ECEC system in England, which until 1998 evolved in the absence of any large-scale government intervention, has exhibited strong continuity as a profoundly mixed economy with a large private for-profit sector in both care and education for the under-5s (Penn and Randall, 2005, Brind et al., 2014) ${ }^{3}$ However, there has been a major change in the ideas driving policy since 2010, when the Conservative/Liberal Democrat Coalition took power with a commitment to austerity. Hence there have also been changes in policy goals, settings and instruments and in the approach taken to issues crucial for ECEC policy, which mean in turn that policy coherence - a problem noted by Wincott (2006) - may have deteriorated. In particular, we address what have been commonly agreed in English policy documents since the mid-20oos (HMT et al., 2004), by academics (e.g. Gambaro et al., 2014), and by trans-national organisations (particularly OECD, 2006; EC, 2011) to be the main issues and sources of tensions in the development of ECEC policy: availability, affordability and quality.

We begin with a discussion of key concepts, followed by a summary of the main goals of the policies developed by Labour between 1997 and 2010 before documenting how availability, affordability and quality have been addressed since then. We conclude that ECEC policy has shown significant change, but without necessarily securing improvements in all these areas. We argue that this is explained partly by the tensions between policy goals, but crucially by the shift in ideas about the role of the state vis-à-vis the market that have driven changes at all levels of policymaking. These have emphasised the promotion of childcare businesses together with weaker regulation, and in the process have facilitated a market increasingly dominated by groups of providers and chains, with the largest 20 nursery chains having a market share of 10 per cent (DfE, 2015a).

\section{Austerity, Continuity and Change}

The political choice following the financial and economic crisis of the late $2000 \mathrm{~s}$ lay between austerity and stimulus, with the UK choosing the former and the Conservative/Liberal Coalition announcing the biggest cuts in state spending since the Second World War (Farnsworth and Irving, 2015). However, austerity involves big political as well as economic ideas and is about more than cuts, aiming to restore a particular kind of economic equilibrium (Blyth, 2013).

European comparativists had predicted that the rise in social expenditure on childcare and other forms of 'social investment' (Hemerijck, 2013; Bonoli and Natali, 2012) would falter and most likely decrease in face of determination to pursue austerity policies (Schäfer and Streeck, 2013). However, the picture in respect of work/family policies more generally has been mixed (Gregory et al., 
2013). In England, while there have been severe cuts to local authority budgets affecting support for childcare, and to tax credits and benefits that have affected families with young children (Stewart and Obolenskaya, 2015), the overall impact of austerity on participation in ECEC across EU27 member states, including the UK, has been relatively small (Kvist, 2013). Nevertheless, austerity has been used as a political tool as well as an economic policy and even when swingeing cuts are not applied, policy can look different when 'programmed with an austerity lens' (Blyth, 2013a: 742). Thus in the case of ECEC in England, following the election of the Conservative/Liberal Coalition in 2010, policy goals changed such that expenditure on 'childcare' has been justified by reference to promoting mothers' employment above all and much more emphasis has been placed on provision by larger for-profit childcare providers.

It has been difficult, though, for scholars to agree on the amount and nature of change in ECEC policy. For example, while Lewis and Campbell (2007) used Hall's (1993) three dimensions of change - in policy settings, instruments and goals - to argue that the most striking shift under successive Labour Governments was in goals and particularly in the idea that the state should expand ECEC policy (also Morgan, 2013), Daly (2010), using the same framework to look at family policies more generally, concluded that change was confined to settings and instruments. While on the surface it looks as though there was surprising continuity in ECEC policy after the 2010 election, there have been major changes that are in keeping with the idea of austerity regarding the role of the state in relation to the childcare market, in policy goals, instruments (particularly in regulation) and settings (involving cuts to demand-side subsidies) that may result in substantial incremental change (Streeck and Thelen, 2005) over time.

\section{Labour's Legacy 1997-2010}

Labour inherited a very limited role for the state in ECEC: childcare was provided by local authorities for children deemed to be 'at risk', and by private and voluntary day nurseries and childminders for the increasing numbers of children with working mothers. Many four-year-olds, then as now, attended primary school prior to compulsory education at five. In 1998 Labour provided an entitlement to 12.5 hours per week of free early education for 33 weeks a year for all four-year-olds with payments made directly to providers replacing nursery vouchers introduced by the Conservative government in 1996. By 2010, all threeand four-year-olds were entitled to 15 hours a week for 38 weeks a year.

Early years care was funded by a mix of supply- and, mainly, demand-side funding via, first, the childcare element of working family tax credit. This covered 70 per cent and, from 2006, 80 per cent of the cost of a place (up to a specified amount) for low-income families where both parents worked at least 16 hours a 
week. Second, from 2005, vouchers were available to working parents not drawing tax credits, administered by some employers. But parents remained responsible for a large proportion of the fees charged for early years care, and the costs to parents have remained among the highest in EU member states (Alakeson and Hurrell, 2012; OECD, 2014).

No attempt was made to increase provision by the state. The UK is virtually alone in Western Europe in providing early education as well as early years care via the market (Penn, 2007; Stewart, 2013), notwithstanding that, by the mid200os, there was clear evidence that state-provided nursery schools employing trained teachers secured better long-term outcomes for children (Sylva et al., 2004). Successive Labour Governments had multiple policy goals. The first administration focussed largely on increasing availability, driven by the goal of promoting the employment of women. But, by 2004, more emphasis was being placed on child development, with more attention paid to quality (HMT et al., 2004). Labour was committed to securing a reduction in child poverty and ECEC policy was seen both as a way of improving the family economy and as a means of raising children's educational attainment, so reducing their chance of falling into poverty as adults (Lewis, 2009).

The early 2000 s were marked by a series of time-limited, supply-side funded initiatives, including grants to develop infrastructure and provide training, the setting up of Neighbourhood Nurseries in poor areas, and Early Excellence Centres to raise the standard of early years practice. The development of Sure Start Children's Centres (SSCCs), many of which provided ECEC to all families in disadvantaged areas, was a much larger and longer-lived initiative. All these initiatives may be seen as efforts to increase both the quality and sustainability of provision in poor areas, ${ }^{4}$ where the problem of making childcare affordable has been widely recognised in and beyond the UK (e.g. Comptroller and Auditor General, 2004; Van Lancker and Ghysels, 2011; Brennan et al., 2012; Lloyd and Penn, 2015).

In respect of quality, it is assumed that parental choice will push up quality, but choice may be limited by cost, location, lack of information, by parents valuing characteristics not rated highly by child development experts (e.g. new premises) and by the need for continuity of provision (Mocan, 2007; Plantenga, 2012; Mathers et al., 2012). Labour intervened to tackle the issue of quality by initiatives to raise the qualifications of the workforce (including the Transformation Fund for staff training and the Graduate Leader Fund to increase the number of graduates [evaluated positively by Mathers et al., 2011]), by regulating staff/child ratios, introducing an Early Years Foundation Stage framework in 2008, and providing resources to local authorities to fund support and quality assurance schemes. Childminders were allowed to provide free early education from 2004 if they belonged to an approved childminder network providing training. 
While in the period 1997-2010 the focus was more on state intervention in the context of a childcare market, since 2010 the emphasis has been on the childcare market first and foremost.

\section{Policy Development, 2010-15 Policy Goals}

In terms of policy goals, promoting child development and mothers' employment have, since 1998, often been identified as the 'double dividend' of childcare provision but, over time, one or the other has tended to take priority for policymakers.

Between 2010 and 2012, when a Liberal Democrat was the responsible Minister, the child development goal appeared to predominate (Comptroller and Auditor General, 2012). The driver was not so much tackling poverty and disadvantage per se, as had been the case for Labour, but rather the problem of unequal outcomes to be tackled by early intervention to secure 'school readiness' (Heckman, 2006; Ruhm and Waldfogel, 2012; Allen, 2011).

From September 2012, a Conservative became the responsible Minister and the pendulum swung back to focusing more on mothers' employment, and, by 2015, to 'helping parents with the cost of living' (Thomson, 2015) as this became an election campaign issue. Two policy decisions illustrate this: (i) from 2012, local authorities were to encourage providers to offer the 15 hours early education entitlement in sessions as long as 10 hours - so potentially over two days providing flexibility that was clearly more in the interest of working parents than child development (nursery schools and classes generally provide 3 -hour sessions, five days a week) (DfE, 2013a); (ii) the additional 15 free hours, promised by the Conservatives in 2015 for implementation in 2017 and referred to as 'childcare' rather than early years education, is targeted at parents who each earn a weekly minimum equivalent to 16 hours at the level of the national living wage ${ }^{5}$, rather than children. In addition, the commitment to a 'diverse sector' (DfE and DH, 2011: 22) with a large place for market provision became considerably more visible by 2015, by which time the desire to promote a growing market sector as a policy goal in and of itself figured more prominently in government documents and speeches made by ministers (e.g. Gyimah, 2015a). This more subtle change in ideas about the place of the market and the accompanying role of the state also affected the Government's approaches to availability, affordability and (particularly) the regulatory framework associated with quality.

\section{Policy Issues}

Availability: amount and nature of provision

The Coalition honoured Labour's intention to increase the number of free hours of early years education a week to 15 from 2010 for all three- and fouryear-olds. It also provided 15 free hours to the 20 per cent most disadvantaged 
two-year-olds from 2013 and to 40 per cent from 2014. The evidence showing that disadvantaged children benefited disproportionately from high quality early education was cited by the Government when it advocated targeting disadvantaged two-year-olds. However, research evidence showed that children did better in socially mixed settings - thus in universal rather than targeted provision (see Mathers and Smees, 2014; West, 2016). In addition, the core purpose of SSCCs has been revised, such that their main focus has become disadvantaged families rather than universal provision within an area (DfE, 2013b).

The proportion of three- and four-year-olds benefitting from governmentfunded places was high from the outset, reaching 97 per cent and 93 per cent respectively in 2015. Those not benefitting come largely from low-income families (DfE, 2012). The picture for two-year-olds was rather different, with only 58 per cent of those eligible for the free hours benefitting in 2015. Simon et al. (2015) highlighted the high use of informal care by young and unemployed mothers, who are also likely to be disadvantaged. A majority of both two- and three-yearolds in formal care were in the (mainly) private, voluntary and independent (PVI) sector, where staff tended to have lower qualifications (HL, 2015), whereas a majority of four-year-olds (77 per cent) were in nursery and primary schools. PVI provision has steadily expanded, especially for three-year-olds (from 55 per cent to 59 per cent between 2010 and 2015); moreover, nursery groups and chains almost trebled the number of settings they operated between 2002 and 2015, bringing their share of places to 25 per cent (DfE, 2015a).

The increased numbers of children covered by the free entitlement had to be found places, in and of itself difficult in poor areas, and additionally so in respect of the quality necessary to improve opportunities for disadvantaged two-yearolds. Commenting on the proposed extension of funded places to two-year-olds, the House of Commons' Education Committee (HC, 2013: 4) said that 'we have concerns about the funding, the quality of providers, the availability of places in effective settings and the impact on places for other age groups...'.

Faced with the problem of securing places for two-year-olds Elizabeth Truss, the Conservative Minister responsible for childcare from 2012-14, sought first and foremost to expand the numbers and role of childminders, who historically provided flexible and cheap care, but whose numbers had decreased since 2007. Childminders have long been the least well-qualified group of private providers, yet the Government sought to remove 'barriers to entry' by enabling them to receive funding for the free entitlement and by setting up Childminder Agencies, intended primarily to help establish childminder businesses (HC Debates, 11.6.13: col. 229). However, these have made very slow progress (Ofsted, 2015). Truss and her Conservative successor, Sam Gyimah, also encouraged schools to take more two-year-olds (Gyimah, 2014). However, the rise in the birth rate militates against this as by $2017 / 8$ primary schools will need 9 per cent more places for school-age children (HL, 2015). 
Studies have repeatedly shown that the best quality provision was provided by nursery schools, which had often worked in tandem with SSCCs to provide ECEC, increasingly for the disadvantaged two-year-olds. 58 per cent of nursery schools received an 'outstanding' Ofsted (Office for Standards in Education, Children's Services and Skills) rating compared to only 10 per cent of other formal settings (Early Education, 2014). But the number of three- and four-yearolds attending nursery schools has declined since 2011 (DfE, 2015b), and around a quarter of SSCC sites are at risk of closure or face uncertain futures (4Children, 2015). In addition, the obligation for SSCCs to provide ECEC in the 30 per cent most disadvantaged areas was abandoned in 2011. Appearing before the House of Commons' Education Committee, the Minister denied that the decrease in these forms of provision was a problem because they provided only 4 per cent of early education places, ignoring the high quality of their offer (HC, 2013, para.33).

\section{Affordability: for the state and for parents}

ECEC funding comprises demand-side funding of early years care for low-income parents, together with direct funding of providers for early years education. Government expenditure in England on under-fives early education was $\mathfrak{E} 4834 \mathrm{~m}$ in $2009-10$, rising to $\mathfrak{E} 4851 \mathrm{~m}$ in $2013-14$ (2014-15 prices), although it is doubtful whether this increase was sufficient to match the rising fertility rate, which has remained relatively high since 2008 (ONS, 2013).

The OECD reported that government expenditure on pre-school education in the UK was higher than average (OECD, 2012). The Minister, Elizabeth Truss, used this evidence of high costs to government to argue for de-regulation, which it was believed would make the childcare market more efficient (DfE, 2013c). However, as Cooke and Henehan (2012: 3) pointed out, the OECD figures had included costs for children up to six (when compulsory education begins in most European countries). When this was allowed for, the UK was shown to be a 'middle-ranking spender at best'.

Since 2010, significant changes have been made to the funding system for early education. A single funding formula, initiated by Labour in 2007 , was fully implemented by 2011, providing a common framework with all providers funded on the basis of participation not places, and supplements for quality and flexibility permitted. A report by the Comptroller and Auditor General (2012) said that about half the local authorities introducing the single funding formula in 2010-11 had given quality supplements for a high Ofsted score or the employment of higher qualified staff. The extension of the free entitlement to disadvantaged two-year-olds was funded by Government at a slightly higher hourly rate than for three- and four-year-olds (DfE, 2013d). However, commenting on the high cost of providing for two-year-olds the Chief Executive of the Pre-school Learning Alliance (2013) said: 'quality provision simply cannot be provided on the cheap'. 
The level of government funding for the free hours has proved increasingly problematic. A House of Lords Select Committee (HL, 2015: para. 106) reported a 'funding shortfall', which was, crucially, covered by the fees paid by parents buying extra hours of care on top of the free entitlement. ${ }^{6}$ In 2015 the Minister, Sam Gyimah, admitted that private and voluntary providers were suspicious of an extension of the free hours because 'it limits their ability to offer other childcare that may come to them at a higher rate, to be brutally honest... '. (cited in HL Debates, 16.6.15: col 1086). State funding for part-time places had offered private providers some financial security, but its extension was viewed as a threat to profit margins. The new, slightly higher rate proposed by Government for the whole 30 hours of free 'childcare' has thus far not been seen as adequate by providers.

The issue of profit is an unknown quantity, especially for the big childcare chains which have come to occupy an increasingly important place in the provision of childcare and which are more likely to make a substantial profit than smaller providers (Brind et al., 2012). The Government's attempt to analyse childcare costs found that a high proportion of respondents were either 'unwilling or unable' to provide the information requested (DfE, 2015a: 78).

In respect of early years care, the subventions made by government to parents who pay fees to PVI providers and to childminders for extra hours beyond the free entitlement have also undergone change. In 2011 the Coalition Government cut the proportion of costs covered by the childcare element of Working Tax Credit from 80 per cent back to 70 per cent, and in 2013, the Government also announced a new tax-free childcare scheme to replace the vouchers administered by some employers, which reached only one-third of parents paying for care (Family and Childcare Trust, 2014a). The high costs of childcare for parents were acknowledged by the Minister (Truss, 2012). The fee paid for 25 hours for a child over two rose 69 per cent over the period 2005-2015, while inflation measured by the Consumer Price Index rose only 28 per cent (DfE, 2015a). Studies showed the difficulty experienced by working and unemployed parents in paying for childcare (Alakeson and Hurrell, 2012; Borg and Stocks, 2013). The high costs are due to the inadequacy of government funding on the one hand, and unregulated fees on the other (West et al., 2010). Continental European research suggests that subsidising parents and demand, rather than funding places, threatens stability of provision and is unlikely to work in terms of increasing take-up in poor areas (Van Lancker and Ghysels, 2011). Several commentators have pointed out that any rise in the subventions to parents to buy extra hours of care is likely to be matched by higher prices in the absence of a cap on fees (HL, 2015; Rutter, 2015; Paull, 2014).

The approach to affordability, particularly the adequacy of government funding, has been important in shaping the nature of the childcare market. As Gyimah (2015a) implied in a speech to the National Day Nurseries Association, small-scale private providers were unlikely to be as well-placed as big childcare 
groups and chains to cope with the tight margins imposed by the government's funding regime. Chains have increased their market share, but this may put availability at risk - as happened in Australia, when a large chain failed (Brennan et al., 2012) - as well as failing to provide affordable places in poor areas.

Affordability was linked firmly by Government to the goal of increasing mothers' employment. But the cuts to the childcare element of Working Tax Credit and the inability of parents in poor areas to pay the increased prices charged for extra hours beyond the free entitlement posed problems for the sustainability of private provision, and also proved an impediment to the policy goal of increasing mothers' employment. The funding system is complicated, difficult for parents to negotiate, and the costs for parents remain very high, particularly because they have plugged the shortfall in government funding. In fact, as the next section shows, the main policy solution advanced for securing greater affordability during the period 2010-15 has been to 'cut red tape' and therefore costs for providers (DfE, 2013e).

\section{Quality of provision}

The pursuit of quality tends to conflict with ensuring a rapid expansion of places and making provision more affordable within a market system, as well as highlighting the tension between the needs of employed parents and of children. It is also a contested concept. The childcare market relies on consumer choice, but even when information is good, parents are likely to have to prioritise affordability and covering their own working hours. Professional judgement will usually focus most attention on the evidence provided by good outcomes for children and on the input variables associated with regulation and staffing (e.g. Cottle and Alexander, 2012). Research evidence has shown that the best outcomes for children taking up the free hours are achieved by public nursery schools (Sylva et al., 2004). However, these are small and more expensive to run in large part because staffing requirements and qualifications are higher than in the private sector; their numbers have not increased.

Government's approach to the issue of quality has changed since 2010. Childcare provision has long been subject to regulation, given that it is a public good with social as well as private consequences (Paull, 2014; see also Folbre, 2008). However the deregulation of the early years sector has been a stated Government aim (Gove, 2012), with the emphasis put on 'freeing' providers to offer more high-quality places with more flexible hours, to invest in high-calibre staff, and to provide more choice for parents (DfE, 2013e).

The levers that Government has historically been able to pull are structural, focusing particularly on registration of providers and inspection, improving staff qualifications, and setting ratios of staff to children (Gormley, 2000). All these offer evidence of recent efforts to deregulate. 


\section{(i) Registration and inspection}

Inspection was relaxed for the more affordable childminders who were no longer subject to individual inspection if they joined the new Childminder Agencies, yet the agencies were designed to provide childminders with 'business support' (DfE, 2014a), rather than the promotion of good practice and training as in the case of the childminder networks encouraged by Labour. This measure was included in the 2015 Small Business Enterprise and Employment Act; the notes accompanying the Bill acknowledged that the aim of the policy was to promote 'a prosperous and growing childcare market' (HC, 2015).

The role of local authorities has also been curtailed. Since 2014, they have not been permitted to use their own assessments of quality when making decisions about which providers can receive funding for the free hours, nor are they able to incentivize quality via their own assurance schemes. Instead, Ofsted has become the sole arbiter of quality (DfE, 2014b), notwithstanding that academic researchers have criticised the extent to which Ofsted's measure of quality shows a poor correlation with other measures (Mathers et al., 2012). In the view of the Government, local authorities were being 'freed' to concentrate on 'identifying and supporting disadvantaged children to take up their early education place' (DfE, 2013a: 4).

\section{(ii) Workforce and ratios}

The early years workforce in the UK is low paid and low qualified compared to most other Western European countries (DfE, 2013f; EC et al., 2014). In an independent review of qualifications (commissioned by government), Professor Cathy Nutbrown (2012) proposed a clear career ladder with qualifications at level 3 (upper secondary education) becoming the minimum standard, leading to 'early years teacher' with qualified teacher status. However, she did not recommend a graduate-led workforce (as per French provision for three-, four- and five-yearolds) or the introduction of a substantial post-18 specialised education (as per the three-year qualification in the Netherlands).

The Coalition abolished Labour's earmarked grant to improve workforce training and graduate leadership; instead, it strengthened the entry requirements for those seeking a level 3 childcare qualification, and accepted the idea of early years teachers in 2013, albeit without granting crucial parity with school teachers. In 2013, while 87 per cent of staff in formal settings were qualified to level 3 , the figure for childminders was only 66 per cent (Brind et al., 2014).

Thus, since 2010, there has been only qualified support by central government for intervention to further improve qualifications. The first major Coalition document on the early years stated that 'employers have primary responsibility for the quality and effectiveness of their staff (DH and DfE, 2011: 64, our 
italics), a position in harmony with the 'hands-off approach to regulation. The 2012 survey of provider finances noted that providers felt that there was some need for staff training, but this was not seen as 'a massively pressing concern' (Brind et al., 2012: 4). In marked contrast to nursery and primary schools, which have qualified teachers, only 13 per cent of paid staff in mainly for-profit, full-day care settings employ a teacher (DfE, 2015a). Most staff are low qualified (especially in poor areas), earning little above the minimum wage (Gambaro, 2012).

The debate about deregulation and quality came to a head over the issue of staff-to-child ratios, which had been clearly specified by Labour. A key Government document (DfE, 2013c) set out the Minister's wish to relax the ratios for all ages of pre-school children and to encourage providers to hire a qualified teacher, which would enable them to move from a 1:8 to a 1:13 ratio for three- and four-year-olds. The Minister also wanted childminders to be able to look after up to four, rather than three, children under five (with no more than two under one). Government suggested that the existing ratios drove both higher costs for parents and lower pay for staff and cited the example of France to support the case for relaxed ratios (DfE, 2013c), but without making clear the differences between the workforce in the two countries. Relaxing ratios in a country with a low qualified and low paid workforce posed difficulties and aroused major opposition from Nutbrown, as well as private sector providers' organisations and groups such as Mumsnet and Netmums who backed the 'Rewind on Ratios' Campaign (HC Debates, 11.6.13: col. 231). Most damagingly, the Liberal Coalition partners withdrew their support (ibid: cols. 236-7) and this dimension of deregulation was dropped.

The main reason why the debate over ratios was so intense was that the Minister responsible for childcare saw it as a particularly important opportunity to tackle all the main issues of affordability, availability and quality. The higher ratio permitted by the presence of a teacher would make it possible to take more children, which in turn would financially benefit providers and hence, it was hoped, parents (by lowering fees), and staff (by raising pay), while also securing better quality childcare (DfE, 2013c, 2015a). Furthermore, Government anticipated that the new ratios would encourage larger group providers or chains, which could 'work the higher ratios and, therefore, bring in enough income to support that higher salary' (HL, 2014, Q4).

The different dimensions of policy lacked consistency in relation to promoting quality; for example there was as much encouragement and more practical support for childminders than for increasing the proportion of graduates in the workforce. Deregulation has been key to Conservative thinking on quality which has centred on the promotion of the childcare market first and foremost and, alongside that, the restriction of government intervention actively to promote quality at both central and local levels. 


\section{Conclusion}

Since 2010, the Coalition and Conservative Governments have shown a continued commitment to ECEC, honouring the Labour promise to extend free entitlement to 15 hours to disadvantaged two-year-olds as well as three- and four-year-olds, and going further than Labour in their promise to double the free hours for three- and four-year-olds by 2017. Deep continuities in the childcare system also persist, above all the increasingly large role of for-profit provision in early years education and care, with a greater market share going to nursery groups and chains. The changes to settings and instruments have been significant and occasionally controversial, particularly in the case of regulation. In short, there have been changes to the way in which the key issues in childcare policy have been addressed, as well as in policy goals. Promotion of the childcare market in particular has been driven by the political ideas about the role of the state that have been part and parcel of the commitment to austerity.

Availability, affordability and quality are all important in ECEC provision and the balance between them has been affected by which main policy goal has been accorded priority: child development or mothers' employment. While Labour's priority shifted from mothers' employment to child development in tandem with the desire to address child poverty, the priority since 2010 has moved in the opposite direction, from child development to increasing mothers' employment. This is in keeping with the economic goals dictated by austerity politics, as shown by the labelling of the new 15-hour entitlement for working parents as 'childcare' and the restriction of provision for disadvantaged two-yearolds to working parents.

The Coalition Government showed particular awareness of the problems of availability and affordability in the major documents it produced in 2013 (DfE, 2013c,e). To address the former, it focused mainly on seeking to encourage the entry of (cheaper) childminders into the market. The major expansion of early years' education rested largely on formal provision by the PVI sector, which also tends to have lower Ofsted ratings, especially in poorer areas, and to have lower qualified workers. Affordability for government and for parents has continued to be a problem. The low amounts paid to providers of the free hours have also rendered the dependence of PVI providers on the fees paid by parents for extra hours more acute if sustainability is to be ensured (West et al., 2010). The parallel increase in market share of larger childcare providers reflects their greater ease in managing tight margins imposed by the government's funding regime and their capacity to do so without local authorities' support.

Despite acknowledging concern about affordability for parents, the percentage of costs covered by the childcare element of Working Tax Credit was cut. No progress has been made in holding down costs for parents and it is not clear how this can be accomplished unless the state increases the amount it is prepared 
to pay private providers and sets limits on what can be charged to parents, or goes much further and effectively abandons market principles, funding places or staff rather than participation. ${ }^{7}$ This would also be more likely to secure sustainable provision in disadvantaged areas (Van Lanker and Ghysels, 2011).

It is also possible to see an important shift in the approach to regulations designed to secure quality: these have increasingly been seen primarily as an impediment to availability and affordability, rather than as means of securing better outcomes for children. Loosening regulations was viewed as a way of securing a more efficient childcare market which would result in more provision becoming available and a reduction in the fees paid by parents.

Many regulations intended to secure quality provision under Labour were abandoned in the name of cutting duplication and red tape. This has entailed a smaller role for local authorities, with Ofsted now the 'sole arbiter of quality'. However, unease expressed by providers as well as campaigners, think tanks and politicians about the proposal to change staff/child ratios was such that the proposal was dropped. While the central issue - for quality - of the low qualifications held by the childcare workforce was addressed in part, the reform did not lead to a graduate-led workforce being established, even though evidence points to positive impacts where staff are highly qualified, as in Denmark and France (West, 2016). Governments since 2010 have continued to accept a role for the state in funding childcare and are to expand this further. However, it is unlikely that such expenditure will promote the kind of long-term social investment needed to achieve an increase in child attainment, so long as the quality of provision remains highly variable with teachers in state-maintained but not in private settings. Debates about quality have been interpreted in ways that seemed to run counter to research findings. In the short-term the political goal of helping 'working families' manage the cost of living has predominated, although spending cuts beyond childcare in the period 2010-2015 have had a disproportionate effect on families with children (Stewart and Obolenskaya, 2015). This further reinforces the assessment of more funding for childcare as instrumental in nature, designed to serve economic policy goals dictated by austerity (cf. Saraceno, 2015).

Indeed, the shifts in Government policy on childcare in respect of the policy instruments of targeting and universalism appear to have exacerbated existing policy incoherence. Most strikingly, targeting disadvantaged two-year-olds for the free hours entitlement now sits alongside universal provision of the first 15 hours for three- and four-year-olds. Disadvantaged two-year-olds are increasingly unlikely to experience the social mixing that has been shown to result in better outcomes and which requires a commitment to universal provision. In addition, two- and three-year-olds more often experience the poorer quality provision offered by PVI providers, while efforts to improve radically the qualifications of the workforce have stalled. 
In fact, it has become increasingly clear that a major goal of Conservative Ministers is to ensure that the childcare market, worth an estimated $\mathfrak{E}_{4}$.9bn in 2013-14 (Gyimah, 2015b), is promoted and remains healthy (see also Lloyd, 2015). The main preoccupation is to ensure market competition free from bureaucratic control, which it is believed will make more provision available and affordable. According to the Minister, it is not for government to say that one form of childcare is better than another, nor to prescribe the wage rates or quality of staff (Family and Childcare Trust, 2014b). Governments since 2010 have tended to make heroic assumptions about the possibility of ensuring high-quality provision by limiting duplication and red tape, even though the combination of PVI providers, the expenditure of significant amounts of public money, and the desire to improve child development might be expected to signal the need for stricter regulation. But from the point of view of Government's focus on childcare businesses, policy is coherent. Indeed, the development of ECEC policy through the lens of austerity (Blyth, 2013a) has resulted in an important change in emphasis in ideas and approach since 2010, giving as much importance to supporting and extending the market (with a marked increase in childcare groups and chains), as to increasing children's achievement and mothers' employment.

Both Labour and the Governments since 2010 have taken the existence of a childcare market for granted; the main policy change has been at the level of ideas about the role of the state. Austerity politics do not rule out state intervention (Farnsworth and Irving, 2015), rather the Coalition and Conservative Governments have shown little enthusiasm for 'positive' intervention of the kind designed to secure a better regulatory framework benefiting children, or to raise the skills of the workforce. Instead, they have been more eager to limit the role of the state to 'negative' intervention designed to remove 'red tape'. It is also significant that much regulation was channelled through the Department for Business, Innovation and Skills. The changes made to the childcare system in terms of settings and instruments since 2010 have been incremental, but the direction of travel signalled by the shift in thinking may become more significant over the next few years, putting the delivery of availability, affordability and quality by a fragmented childcare market further in doubt.

\section{Notes}

1 The 2006 Childcare Act included early years education in this term, allowing policymakers to conflate early years education and early years care.

2 Early years education and care is devolved in the UK.

3 Only the Dutch rely to a similar extent on demand-side funding, and only for early years care under 4 .

4 Significant concerns about sustainability were also expressed within government (see Campbell-Barr, 2009 for details).

5 Unless one parent is disabled or a carer, or in transition from parental leave or paid sickness leave to paid work. 
6 A $\mathfrak{E}_{300}$ 'pupil premium' introduced in 2015 for children from low income families may also have helped to address this problem, although its stated aim was to improve quality.

7 e.g. as happens in France (West, 2016).

\section{References}

4Children (2015), Children's Centre Census 2015, London: 4Children.

Alakeson, V. and Hurrell, A. (2012), Counting the costs of childcare, London: Resolution Foundation.

Allen, G. (2011), Early Intervention: the next steps. An independent report to HM Government, London: The Stationery Office.

Blanden, J., Del Bono, K., McNally, S. and Rabe, B. (2016), 'Universal pre-school education: the case of public funding with private provision', Economic Journal 126, issue 592, 682-723.

Blyth, M. (2013), Austerity: The history of a dangerous idea, Oxford: Oxford University Press.

Blyth, M. (2013a), 'Austerity as ideology: a reply to my critics', Comparative European Politics $11,6,737-751$.

Bonoli, G. and Natali, D. (2012), The politics of the new welfare state, Oxford: Oxford University Press.

Borg, I. and Stocks, A. (2013), A Survey of childcare and work decisions among families with children, London: DWP.

Brennan, D., Cass, B., Himmelweit, S. and Szebehely, M. (2012), 'The marketisation of care: rationales and consequences in Nordic and liberal care regimes', Journal of European Social Policy 22, 4, 377-391.

Brewer, M., Cattan, S., Crawford, C. and Rabe, B. (2014), The Impact of free, universal pre-school education on maternal labour supply, London: IFS.

Brind, R., Norden, O. and Oseman, D. (2012), Childcare provider finances survey. DFE-RR213, London: DfE.

Brind, R., McGinigal, S., Lewis, J. and Ghezelayagh, S. (2014), Childcare and early years providers survey, 2013, TNS BMRB Report JN117328. London: DfE.

Campbell-Barr, V. (2009), 'Care and business orientations in the delivery of childcare', Journal of Early Childhood Research, 7, 1, 76-93.

Comptroller and Auditor General (2004), Early years: progress in developing high quality childcare and early education accessible to all, HC 268. London: The Stationery Office.

Comptroller and Auditor General (2012), Report. Delivering the free entitlement to education for three- and four-year olds. HC 1789, London: The Stationery Office.

Cooke, G. and Henehan, K. (2012), Double Dutch. The case against deregulation and demand-led funding in childcare, London: IPPR.

Cory, G. (2015), 'Consensus breaks out over childcare', New Statesman 21 April.

Cottle, M. and Alexander, E. (2012), 'Quality in early years settings: government, research and practitioners' perspectives', British Educational Research Journal 38, 4, 635-654.

Daly, M. (2010), 'Shifts in family policy in the UK under New Labour'. Journal of European Social Policy 20, 5, 443-443.

DfE (2012), Provision for children under five years of age in England: January 2012. Statistical first release, London: DfE.

DfE (2013a), Early Education and Childcare. Statutory Guidance for local authorities, London: DfE.

DfE (2013b), Sure Start Children's Centres Statutory Guidance for local authorities, commissioners of local health services and Jobcentre Plus, London: DfE

DfE (2013c), More great childcare. Raising quality and giving parents more choice, London: DfE.

DfE (2013d), E755 million to double free childcare offer for 2-year-olds, Press Release, 18 December.

DfE (2013e), More affordable childcare, London: DfE.

DfE (2013f), Evidence to inform the Childcare Commission: Part 1 - international evidence on childcare policies and practices, London: DfE.

DfE (2014a), Childminder agencies and changes to the local authority role, London: DfE. 
DfE (2014b), Early education and childcare. Statutory Guidance for local authorities, London: DfE.

DfE (2015a), Review of childcare costs: the analytical report. DFE-00295-2015, London: DfE.

DfE (2015b), Provision for children under five Years of age in England: January 2015, London: DfE, Tables 3, 13, 13a.

DfE and DH (2011), Supporting families in the foundation years, London: DfE.

EC (European Commission) (2011), Communication from the Commission: early childhood education and care: providing all our children with the best start for the world of tomorrow, COM (2011) 66. Luxembourg: Author.

EC/EACEA/Eurydice/Eurostat (2014), Key data on early childhood education and care in Europe. 2014 Edition. Eurydice and Eurostat Report, Brussels: EACEA.

Early Education (2014), Maintained nursery schools: hubs for quality in the early years, London: British Association for Early Childhood Education.

Family and Childcare Trust (2014a), Where next for childcare? London: Family and Childcare Trust.

Family and Childcare Trust (2014b), Annual Conference, 25 November. Own notes.

Farnsworth, K. and Irving, Z. (eds.) (2015), Social policy in times of austerity, Bristol: Policy Press.

Folbre, N. (2008), Valuing children: rethinking the economics of the family, Cambridge, MA: Harvard University Press.

Gambaro, L. (2012), Why are childcare workers low paid? An analysis of pay in the UK Childcare sector, 1994-2008, Unpublished PhD thesis, The London School of Economics and Political Science.

Gambaro, L., Stewart, K. and Waldfogel, J. (eds.) (2014), An equal start? Providing quality early education and care to disadvantaged children, Bristol: Policy Press.

Gormley, W. R. (200o), 'Early childhood education and care regulation: a comparative perspective', International Journal of Educational Research 33, 1, 55-74.

Gove, M. (2012), 'Requirements for early education and childcare inspections'. Letter to Wilshaw. 11 July.

Gregory, A., Milner, S. and Windebank, J. (2013), 'Work-life balance in times of economic crisis and austerity', International Journal of Sociology and Social Policy 33, 9/10, 528-541.

Gyimah, S. (2014), 'Why Schools should be involved in nursery provision', Speech at Policy Exchange 21 October.

Gyimah, S. (2015a), Speech at National Day Nurseries Association Conference, London, 14 January.

Gyimah, S. (2015b), Speech to Nursery World Business Summit, London, November 11.

Hall, P. A. (1993), 'Policy paradigms, social learning, and the state: The case of economic policymaking in Britain', Comparative Politics 25, 3, 275-96.

Heckman, J. (2006), 'Skill formation and the economics of investing in disadvantaged children', Science 312, 5782, 1900-1902.

Hemerijck, A. (2013), Changing Welfare States, Oxford: Oxford University Press.

HC (House of Commons) (2013), Education Committee Foundation years: Sure Start Children's Centres, HC364-I.

HC (2015), Small Business, Enterprise and Employment Bill, Explanatory Notes, para 50.

HL (House of Lords) (2014), Select Committee on Affordable Childcare. Oral and Written Evidence, DfE, 9.7.14, London: The Stationery Office.

HL (2015), Select Committee on Affordable Childcare. Report. HL Paper 117. London: The Stationery Office.

HMT (Her Majesty's Treasury), DfES, DWP and DTI (2004), Choice for parents, the best start for children: a ten-year strategy for childcare, London: Treasury.

Kvist, J. (2013), 'The post-crisis European Social Model: developing or dismantling social investments?' Journal of International and Comparative Social Policy 29, 1, 91-107.

Lewis, J. (2009), Work-family balance, gender and policy, Cheltenham: Edward Elgar. 
Lewis, J. and Campbell, M. (2007), 'Work/family balance policies in the UK since 1997: a new departure?', Journal of Social Policy 36, 3, 365-382.

Lloyd, E. (2015), 'Early childhood education and care policy in England under the Coalition Government', London Review of Education, 13, 2, 144-156.

Lloyd, E. and Penn, H. (2015), 'Childcare markets in an age of austerity', European Early childhood Education Research Journal, 22, 3, 386-396.

Mathers, S., Ranns, H., Karemaker, A., Moody, A., Sylva, K., Graham, J. and Siraj-Blatchford, I. (2011), Evaluation of the Graduate Leader Fund. Final report, Research Report DFE-RR144, London: DfE.

Mathers, S., Singler, R. and Karemaker, A. (2012), Improving quality in the early years. A comparison of perspectives and measures, London: Nuffield Foundation.

Mathers, S. and Smees, R. (2014), Quality and Inequality, London: Nuffield Foundation.

Mocan, N. (2007), 'Can consumers detect lemons? An empirical analysis of information asymmetry in the market for child care', Journal of Population Economics 20, 4, 743-780.

Morgan, K. J. (2013), 'Path shifting of the welfare state. Electoral competition and the expansion of work-family policies in western Europe', World Politics 65, 1, 73-115.

Nutbrown, C. (2012), Foundations for quality. The independent review of early education and childcare qualifications, Final Report, London: DfE.

OECD (Organisation for Economic Cooperation and Development) (2006), Starting strong II. Early childhood education and care, Paris: OECD.

OECD (2012), Family Database, PF3.1: Public Spending on Childcare and Early Education, Paris: OECD.

OECD (2014), Family Database, PF3.4: Childcare Support, Paris: OECD.

Ofsted (2015), Early years report, London: Ofsted.

ONS (2013), 'Why has the fertility rate risen over the last decade in England and Wales?' 17/6/13 (part of Birth Summary Tables - England and Wales. First Release), London: ONS.

Paull, G. (2014), 'Can government intervention in childcare be justified?' Economic Affairs 34, 1, 14-34.

Penn, H. (2007), 'Childcare market management: How the United Kingdom Government has reshaped its role in developing early childhood education and care', Contemporary Issues in Early Childhood 8, 3, 192-207.

Penn, H. and Randall, V. (2005), 'Childcare policy and local partnerships under Labour', Journal of Social Policy 34, 1, 79-97.

Plantenga, J. (2012), 'A market for childcare services? Private provision and public finance in the Dutch childcare sector'. In D. G. Mayes and M. Thomson (eds.), The costs of children. Parenting and democracy in contemporary Europe, Cheltenham: Edward Elgar.

Pre-School Learning Alliance (2013), 'Alliance disappointed by continued underfunding of two-year-old offer'. Press release, London, 18 December.

Ruhm, C. and Waldfogel, J. (2012), 'Long-term effects of early childhood care and education', Nordic Economic Policy Review 18, 1: 23-52.

Rutter, J. (2015), Childcare costs survey 2015, London: Family and Childcare Trust.

Saraceno, C. (2015), 'A critical look to the social investment approach from a gender perspective', Social Politics 22, 2, 257-269.

Schäfer, A. and Streeck, W. (2013), Politics in the age of austerity, Cambridge: Polity Press.

Simon, A., Owen, C. and Hollingworth, K. (2015), Provision and use of preschool childcare in Britain, London: Thomas Coram Research Unit, Institute of Education, UCL.

Stewart, K. (2013), Labour and the under-fives: policy, spending and outcomes 1997-2010, Social Policy in a Cold Climate, working paper 4. London: CASE, LSE.

Stewart, K. and Obolenskaya, P. (2015), The Coalition's record on the under-fives: policy, spending and outcomes 2010-2015, Social Policy in a Cold Climate, working paper 12, London: CASE, LSE.

Streeck, W. and Thelen, K. (2005), (eds.), Beyond continuity. Institutional change in advanced political economies, Oxford: Oxford University Press. 
Sylva, K., Melhuish, E., Sammons, P., Siraj-Blatchford, I. and Taggart, B. (2004), The effective provision of pre-school education (EPPE) project: effective pre-school education, final report 1997-2004, London: DfES.

Thomson, R. (2015), 'Exclusive interview with Childcare Minister Sam Gyimah: France, funding and the 30 hours', Nursery World October 19.

Truss, E. (2012), Affordable quality: new approaches to childcare, London: CentreForum.

Van Lancker, W. and Ghysels, J. (2011), Who reaps the benefits? GINI Discussion Paper 10, Antwerp: University of Antwerp, GINI.

West, A. (2016), Nursery education and reducing social inequalities: an international comparison of early childhood education and care, Paris: Cnesco.

West, A., Roberts, J. and Noden, P. (2010), 'Funding early years education and care: can a mixed economy of providers deliver universal high quality provision?' British Journal of Educational Studies, 58, 2, 155-179,

Wincott, D. (2006), 'Paradoxes of New Labour social policy: toward universal child care in Europe's “most liberal” welfare regime?', Social Politics 13, 2, 286-312. 